\title{
Ethical Dilemma Faced by General Motors India
}

\author{
Thomas Mathew
}

\begin{abstract}
This paper analyzes the ethical dilemma faced by General Motors India with relation to the regulatory norms imposed by the Government. The dilemma is mainly due to the aggressive sales intention of GM to achieve their strategic intent with relation to the problems faced to comply with the emission regulation norms. A shift in the approach from the "Utilitarian" view to the "Kantian" model helps GM India to resolve the huge product recall that was faced by GM India.
\end{abstract}

Index Terms-Ethical dilemma, GM India, Kantian model, utilitarian view.

\section{INTRODUCTION}

General Motors has being doing business in India from 1928 where they were assembling Chevrolet cars, buses and trucks, however they ceased assembly operations in 1954 and in 1994 they reentered forming a 50-50 joint venture with Hindustan Motors in wherein they produced and sold the Opel brand vehicle. Subsequently in 1999 GM took full control of production and sales when they bought out the Hindustan Motors interest. Their production facility is located at Halol, Gujarat. It was at this location that they started the production of Chevrolet in the year 2003.

They are headquartered at Gurgaon and have their technical center operations in Bangalore that is including research and development along with vehicle engineering activities. This technical center now includes purchasing and handles the financial support services for General Motors operations located outside of India including vehicle engine, transmission design and engineering with a vehicle design studio. They also have a second vehicle assembly plant located in Talegaon, Maharastra that produces Chevrolet vehicles from September 2008.

Their Halol and Talegaon Manufacturing facilities have a combined Production Capacity of 385,000 vehicles annually. GM has their independently owned dealers who sells, service and market vehicles produced by them. Founded in 1911 in Detroit, Chevrolet is one of the world's largest car brands, doing business in more than 140 countries. Chevrolet is the world's-fastest growing major automotive brand having sold more than 4.95 million vehicles in 2012 that is a global sales record driving their global sales to more than 9.2 million vehicles that is a 2.9 percent increase compared to their 2011 sales.

The United States was the largest individual market for Chevrolet with vehicle sales of 1.85 million however 60 percent of their sales came from markets like Brazil

Manuscript received August 26, 2013; revised November 10, 2013.

T. Mathew is with the K. J. Somaiya Institute of Management Studies \& Research, Mumbai University (e-mail: thomas@somaiya.edu, saintl@vsnl.com).
$(643,000)$, China $(627,000)$, Russia $(205,000)$, South Korea $(125,000)$ and India $(92,000)$.

As Don Johnson, Vice President of U.S. sales and service said " Chevrolet is most aggressively rolling out new products that has helped GM deliver their ninth-consecutive quarter of record global sales," as this is guided by a new global vision, 'Find New Roads,' that has its roots in the brand's legacy of ingenuity. Chevrolet is poised for continued growth in 2013 with around thirteen new or significantly redesigned products expected to be launched in the United States and around the world.

Chevrolet has global presence by virtue of delivering small cars like the Cruze and Sonic/Aveo

The top 10 Chevrolet sales markets in 2012 is seen in Table I:

\begin{tabular}{|c|c|}
\hline Market & Total 2012 Sales \\
\hline United States & $1,850,000$ \\
\hline Brazil & 643,000 \\
\hline China & 627,000 \\
\hline Russia & 205,000 \\
\hline Mexico & 179,000 \\
\hline Canada & 139,000 \\
\hline Argentina & 134,000 \\
\hline South Korea & 125,000 \\
\hline Uzbekistan & 123,000 \\
\hline India & 92,000 \\
\hline
\end{tabular}

\section{ETHICAL CONCEPTS}

Tough times call for creative solutions, and the widespread failure of our leaders and the rest of us to take ethics seriously create a problem.

According to the 2009 USA Today/Gallup Poll, less than $25 \%$ American in four rated highly the ethical standards of business executives.

Irrespective of you being a CEO of a global corporation or a midlevel manager you need to set high standards in your organization and need to live up to them.

The development of technology has bought up an array of ethical issues that are related to work. In a study on systems that are technology related with an over-reliance on systems that are computer controlled systems there are several issues of management responsibilities and responses. Cordeiro, W. [1] suggested a five-step process for managing these ethical issues effectively. This mainly involved being aware, consistent, and most important to communicate clearly

Beck [2] has defined ethics as "the universal practical philosophy dealing with the intrinsic goodness found in most of the actions.

Sullivan [3] explained that moral decision making is mainly using rational intellect instead of rules prescribed by 
lawmakers. Flew [4] defined rationalism wherein humans can gain knowledge of the something and ethical decisions are guided by deductive reasoning.

S. A. Bowen, [5] studied two global pharmaceutical organizations using the Kantian model for practical implementation dealing with ethical issues. In Kantian philosophy, a decision is truly moral only if made by an autonomous, rational decision maker. Rationality is the guide used by all humans with free choice to fulfill the moral law

The practical implementation of the model asks the decision maker to rule out prudential self-interest, greed, and selfish motives by asking the questions "Am I acting alone on the basis of reason? Can I rule out influence of politics, money, and self-interest?" If the answer is "yes," then the issue manager proceeds to the next step toward decision making that involves the group consensus. The model then proceeds to the most rigorous test of deontological philosophy that is Kant's categorical imperative. This imperative is universal, an absolute standard of principles that applies consistently across time, cultures, and societal norms. This includes the principle of reversibility that means would the decision maker see merit in the decision if he was on the receiving end of this decision.

Kant's argument of actions undertaken from duty is in opposition to the utilitarian school of ethics. Utilitarianism looked at [6] [7] the consequences of an action that create the greatest good or happiness for the greatest number of people. Utilitarianism is a teleological - or consequentiality - based philosophy as opposed to Kantian deontology's non consequentialist, duty-based approach. Utilitarianism is mostly used in cost-benefit analysis.

Kant placed the highest worth on performing moral duty based on rational decision making. The actions undertaken from duty rather than from compulsion or law are important.

"GOOD WILL" [8] according to Kant is a necessary condition for ethical decision making. Baron [9] explains that good will manifest in actions done from duty. People need to be treated as an end in them and never as a means to an end. Every human person has objectives and intrinsic worth or dignity that is accomplished by providing the necessary knowledge to make their own decisions,

This is the "Ethical Consideration Triangle" used to discuss issues in management teams. Each point of the triangle is based on one of Kant's formulations of the categorical imperative: (a) duty, (b) dignity and respect for others, and (c) intention or a morally good will. Inside the triangle, are the group's issues managers should consider with respect to their dignity and respect, duty, and their intentions these groups are publics, stakeholders, self, the organization, and society. Managers need to consider all these groups individually to conduct a thorough analysis of the perspective of each group involved in an issue.

Symmetrical communication, according to J.E. Grunig [10], is when "practitioners use dialogue to bring about symbiotic changes in the attitudes, and behaviors of both their organizations and publics". According to J. E. Grunig and Dozier [11] the symmetrical approach to communication is inherently more ethical than the other approaches because it is based on dialogue. It is the moral duty to engage in dialogue [12].
The communication should be ongoing that is used to contribute to the decision-making process as well as to communicate with publics about the decision. This is seen in Fig. 1.

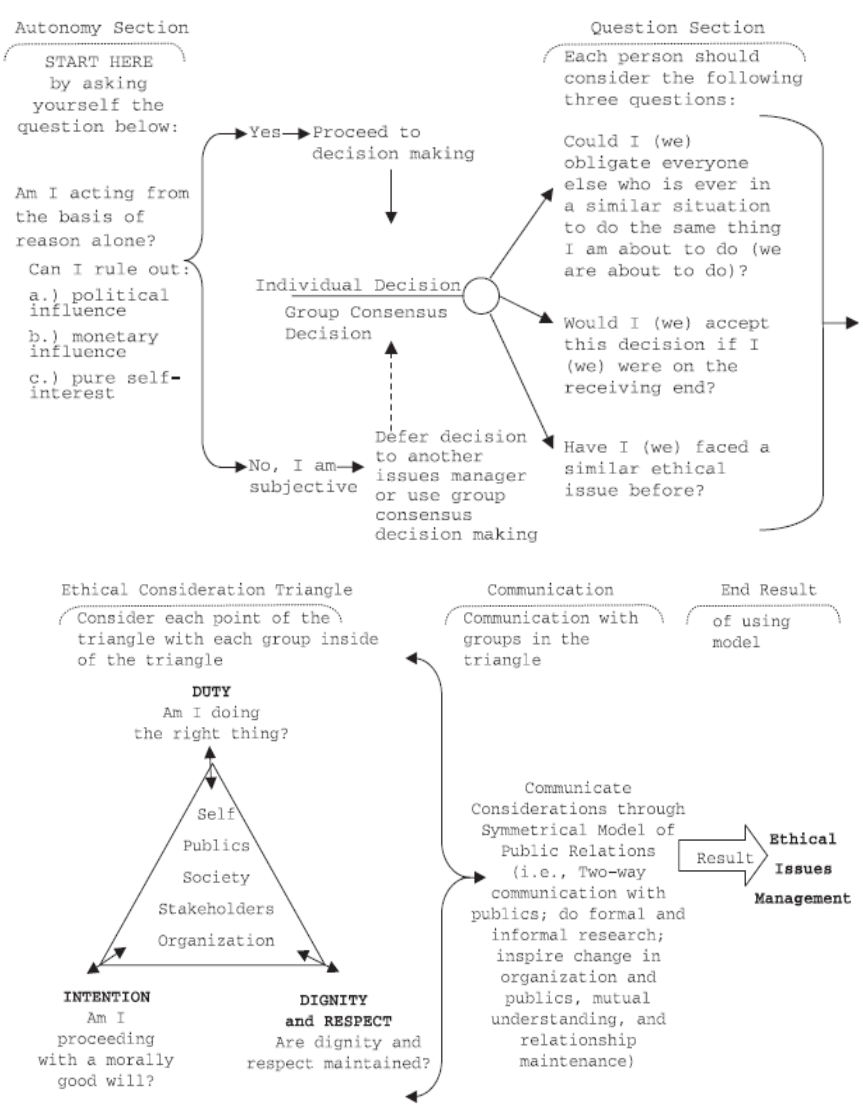

Fig. 1. Practical model based on Kantian Ethics.

\section{ETHICAL DECISION - ECONOMIC IMPACT}

A company's brand name takes years to develop hence it the most valuable asset. If the trusted brand causes harm to the customer then it can irreparably harm the brand image. Product recalls have increased dramatically especially in the US as per the U.S. Consumer Product Safety Commission's website. Among the various costs associated with a product recall the cost of losing customer goodwill is very crucial affecting the sales of the company.

Based on the stock market reactions to automotive recalls in the U.S. from 1966-2011 there is evidence that the firms initially experience abnormal returns of $-0.6 \%$. Furthermore the customers future purchase decision would depend on the extent to which the company can show the reliability of the specific aspects of their goods and services. [13]

D. Vogel, [14] clearly shows the distinctive differences of the United States as compared to the rest. Americans consider the individual as critical for the source of ethical values compared to the other nations where the corporation is the locus for ethical guidance. This means the managers when facing a moral dilemma in non US nations would make decisions based on their shared understanding of the scope and nature of the company's responsibilities. This is based on the norms of the community thus resulting in "consensual" business ethics rather than on their personal values. 
Furthermore United States businesses have increased protection from the whistle blowers especially for violation of regulatory statutes by slack company policies. Instead non-US companies have the greater emphasis on informal control mechanisms within the firm. Another crucial area is that Americans tend to believe that the American procedures and rules should be applied universally. This 'universalism' makes a distinction between "us" and "them", wherein the American business culture treats everyone in the same arm's length. The others in contrast define their ethical responsibilities wherein they place less value on treating everyone equally and attach more importance in fulfilling the obligations to those institutions that they have long standing relationships. The application of business ethics in any situation of global integration needs the better appreciation of the differences in the legal and cultural context of the business environment between United States, Western and the Asian economies.

E. D. Jaffe and A. Tsimerman, [15] studied Russian managers who are not adopting an ethical modicum of behavior as they have very low ethical threshold and they believe that it is necessary to compromise one's ethics for self-interest rather than that of one's organization or their society. This is mainly due to failure of proper ethical education at the business school level.

P. T. Heyne, G. Brennan, and A. M. C. Waterman, [16] argues that the ethicist or market skeptic suffers from The Fatal Conceit: "The widespread moral suspicion that economists specialize in the analysis of social systems that no one controls and that produce results that no one intended"

There is the fear of the unknown (and unknowable) that explains their distrust of the market economy and their enthusiasm for planning. Sometimes people's opportunities are so poor that we should offer them somewhat better opportunities?

B. A. B. Blonigen, C. R. C. Knittel, and A. Soderbery, [17] have studied the product redesigns happening across virtually all types of products and analyzed the redesign activity in the U.S. automobile market. They found that automobile model designs become obsolete quickly resulting in frequent model redesigns despite an estimated average redesign cost of around \$1 billion. Their model estimates showed that companies' redesign decisions depend crucially on competition for market share and the planned obsolescence of the existing model design. Redesigns lead to substantial profits based on the strong preferences of the customer. Therefore companies are very keen to increase their market share for strategic reasons.

It is estimated that the cost of redesigning automobiles varies between $\$ 500$ million and $\$ 1$ billion dollars. If the customers' expectations of quality are high then the manufacturers may find that they are unable to shift expectations of product quality as they have to cover such large redesign costs, thus losing their market share to reputable higher-quality producers. This can be further confounded by the country attribution to the quality of the product.

R. G. Hammond, [18] studied consumer responsiveness to large-scale product recalls that are caused by safety problems of the automobile industry, where 22.4 million recall notices were issued during 2010. In fact more new and used vehicles were recalled in 2010 than were sold in 2010. The most widely covered recall was of Toyota Motors vehicles due to safety issues called "sudden unintended acceleration." $\mathrm{He}$ compared the recall of Toyota vehicles to those of the Audi vehicles during the 1980s. An analysis of the Toyota recalls in 2009-2010 in comparison to similar recalls for the Audi $5000 \mathrm{~S}$ in the late 1980's showed a larger drop in Audi brand vehicles during their major recall. This was because customers were much less familiar with Audi who were a relatively new entrant to the U.S. market. Thus the more familiar customers are with the company generally; the less does a recall affect the product quality expectations.

The comparison between the two recalls highlighted that the recall on Toyota had small effects on the consumer demand primarily due to Toyota's reputation that was more established in the American market.

J. E. Alvey, [19] showed the relationship between ethics and economics. "Human ends" are subjective and beyond rational debate whereas "means" are subject to rational debate and economics focuses on them. It is claimed that goals can be altruistic or public spirited. The 'scientification' of economics has led to a separation of economics from its ethical roots as science is concerned with 'facts.'

J. C. Lere and B. R. Gaumnitz, [20] studied the impact of the code of ethics in decision making and observed that the individual behavior is not much affected by the code of ethics, however the likelihood that an individual will select an action that is ethical based on code of ethics increases if such a code is supplemented with sufficient provisions to enforce them coupled with extrinsic deterrents provided by the organization. Unethical behavior depends on amount of benefits that an individual gets coupled with the imposing pecuniary and non-pecuniary penalties that the organization would impose on those individuals.

C. Barnes, [21] emphasized the pragmatist view of leadership in understanding both the strengths and weaknesses of our economic and political system to make ethical decisions thereby fostering an ethical culture that will make organizations more successful. The commitment to ethics must come from the top to motivate, empower and encourage employees to achieve. Pragmatism in leadership necessitates a look at the consequences of the changing environment and incorporates their implications into policies which reflect the real world experience. This reflects a greater moral understanding that influences the global economic life.

A. Jamnik, [22] studied the integration of ethics and economics in the modern world. Business ethicists identify consistent rules that align with rights and justice standards. This is based on the deontological or duty-centered ethics.

The neo-classical economists use the "greatest good" concept of utilitarianism. Traditionally ethics emphasizes the greatest happiness as a moral principle when choosing a course of action simultaneously trying to maximize the good for all. In this case, utilitarianism is used as a moral precept or rule to all situations a priori.

There is a conflict between deontological ethics and economic utilitarianism. Economic utilitarianism focuses on self-gain employing the cost-benefit rule to measure whether 
a desirable net gain accrues to individuals in markets, or to the stockholders as profits. In contrast, the deontological ethics asserts the primacy of duty to others with an emphasis on moral motivation. There is a tradeoff between self-interest and other-concern in which economic goals (of stockholder or company profits) may exist in tension with duty to others (as standards of rights and justice).

This conflict between ethics and economics needs to be resolved. The utilitarian theory does an ethical check involving three questions:

1) Is it legal or violating either civil law or company policy?

2) Is it balanced? Is it fair to all concerned \& promotes win-win relationships?

3) How will it make me/my family feel about myself?

The manager would reconsider his or her decision focused on the basic values.

Based on the stakeholder theory business managers consider the relationship between various interest groups like owners, employees, managers, customers, suppliers, investors, and the entire business environment. This is based primarily on Kantian principles or deontological ethics with the moral values enshrined in the culture and looks at seek justice, doing no harm honor, loyalty, achieving credibility, acknowledging liability, performing charity, fostering personal growth, expressing gratitude, preserving freedom, and practicing respect.

In any business decision there is plurality of values where the challenges and conflicts are overtly hidden making it difficult to relate ethics and economics. There must be a balance of desiring wealth that should not override man's freedom and dignity

\section{PRODUCT RECALLS - ECONOMIC IMPACTS}

Z. Yin, F. Xiaoliang, and H. Minxue, [23] had analyzed the problem faced by business leaders in product recalls due to negative public responses and reputation. They constructed the public response model wherein prior beliefs of the public on the recalled brand influence the product recall strategies.

N. C. Smith, R. J. Thomas, and J. A. Quelch, [24] concluded that product recalls can destroy brands and even companies provided the company handles recalls strategically.

There is a need to address relevant implications of the recall at all stages. They suggest a recall response team to decide and oversee the appropriate response. This needs to be communicated properly through the right channel with proper planning to achieve long-term favorable outcomes.

C. Korkofingas and L. Ang, [25] studied the impact of product-recall experiences on brand-equity measures and, the customers future brand choice. They found that product recall experience has greater negative impacts for established strong brands than the weaker non-established brands. Also the seriousness of the recall problem and speed of recall announcement impacted the customers' pre- and post-recall evaluations of brand equity.

D. Minor and J. Morgan, [26] studied the benefits of corporate social responsibility (CSR) that helps maintain a firm's good reputation when it faces negative publicity due to product recalls. An analysis of stock price trends using the Standard \& Poor's 500 Index along with cases of product recall incidents indicated that companies with higher CSR ratings were more successful at overcoming the setbacks of product recall thereby the necessity for constructing suitable CSR programs in order to protect a companies' corporate image.

A product recall is a request formally made by a company to its customer, to discontinue use of a product that it sold or produced. A recall happens when a product deems to pose a danger to the customer or violates a product safety regulation [27].

A. Zavyalova, M. D. Pfarrer, R. K. Reger, and D. L. Shapiro, [28] studied product recalls of US toy companies from 1998-2007 and investigated how the companies actions influence media coverage of wrongdoing and how this influence varies depending on the source of the wrongdoing. Wrongdoing is a company's behavior that places companies' stakeholders at risk and violates stakeholders' expectations of societal norms and general standards of conduct.

When a company announces technical actions or ceremonial actions the tenor of media coverage varies depending on the wrongdoing and the market competition. "Managing the message" is a strategy that combines both technical and ceremonial actions, depending on whether the company or its competitors are engaged in wrongdoing.

However with wrongdoing that is not properly managed with the media the companies' level of social approval can drop and the stakeholders usually withdraw transactions [29]

Y. Choi and Y. H. Lin, [30] study on Mattel product recalls examined how the media covered crisis responsibility and reputation when their highly involved customers were twice as emotional involved as the normal customers, suggesting the involvement of customer is also vital in product recall situations.

Studying the product market and equity reactions to toy recalls in the US, Freedman, Kearney, and Lederman [31] found that customers had even substituted even from companies whose products were not recalled. This shows that the customers question other exogenous factors like country of origin as a signal of product quality. An analysis for 5900 recalls in the automotive industry over 55 years found that the country of origin also imparts a negative spillover of $-0.15 \%$ on the companies from the same country that recalled the product/service.

It was found that smaller firms that tend to have lower reputations suffered stock losses compared to larger firms with higher reputations. This loss was more severe depending on the severity of the recall. Interestingly in non-auto recalls, it was observed that negative abnormal returns were significantly more when the products are replaced (or the purchase price is returned) than when the products are returned after being checked and repaired. Also, it was found that losses in the stock were the same irrespective of who initiated the recall, i.e., the company or the regulator [32] [33].

D. Laufer and J. M. Jung, [34] looked at the product recall communications with customers during crisis management in the laptop sector. They concluded that the application of 
regulatory focus if communicated well can increase the customers future purchase intentions.

G. Jarrell and S. Peltzman, [35] analyzed the wealth of shareholders of firms producing defective products based on their study on drugs and autos that were recalled from the market. They observed that the losses of shareholders wealth are substantially greater than the costs that emanate directly from the recall like costs of destroying or repairing defective products. The shareholders wealth loss is very large (even larger than the aggregate loss to the producer) and even spills over to the companies "goodwill."

C. A. D. Matos and C. A. V. Rossi, [36] evaluated the factors influencing consumers' responses to product recalls among Brazilian automobile owners and they found that customer response to the product was significantly affected by corporate social responsibility (CSR) than the behavior of the customer. They perceived a company that is familiar to them is usually less responsible for the defect than an unfamiliar company. This shows that the company in an unfamiliar market must be very careful on the quality and also must increase their CSR activities before being very aggressive in sales.

S. Govindaraj, [37] study on Bridgestone Corp tires recall by Ford Motors showed a considerable drop in the market value of the company that was generally in excess of any tangible and direct costs associated with the recalls. The government had to interfere by formulating new transportation regulations.

The harm to the product can ruin the brand equity that was carefully cultivate thereby damaging the company's reputation and leading to loss in revenue and market-share [38]

Rhee and Haunschild [39] study showed that automobile companies who have a strong market reputation experienced greater market share fall due to product recall announcements than those with weaker reputations

Automotive recalls have caused decrease in market share of the involved company and if these recalls were 'sufficiently surprising' that alters the customers' expectations then it would induce a shift toward more reliable alternatives The magnitude of shift would depend on the unexpectedness of the recall and the ability of the customer to identify more reliable alternatives. The decision on reliability is based on the customers' discernment on the product recall if it was due to brand specific characteristics, production processes, or even a country-specific input available to suppliers. This is further complicated by the time taken to release information about the cause of the vehicle recall. However the customer may shift to products produced by the same brand, company, and country of origin if they are unable to discern the source of the problem.

\section{CODE OF CONDUCT}

A Code of conduct for Ethics Czars was proposed by Bruce Weinstein who suggested the following points to be considered by a company that faces an ethical dilemma. It is suggested that GM India follow the same code.

\section{A. Lead by Example}

The most effective way is demonstrating to the members of your team to see that you tell the truth or the way you react to a stressful situation compassionately, owning up your mistakes. This shows your character and team playing capabilities.

\section{B. Praise Generously}

It's very important to tell people when they have done something right. A little praise will go a long way especially when it comes from the heart.

\section{Criticize to Build up, not Break Down}

Good managers should know when criticism is most effective as it leaves someone inspired to do better. Take meaningful criticism seriously when you receive it.

\section{Be Kind, Unwind}

Encourage team members to use their vacation holidays as the value of relaxing is vital. Granting time to unwind is an ethical obligation. This is a great way to apply the ethical principle of love and compassion.

\section{E. Punish Fairly}

Good managers control their anger without influencing the way they punish employees. Decide the appropriate response by putting aside whatever incidents that are emotional that is unrelated to the problem at hand.

\section{F. If It Is to Be, It's up to Thee}

Take proactive action. Avoiding the matter means one is assuming that problems will take care of themselves. It takes courage, and this is where you as a manager need to step up. All problems can't be solved however you need to live much above the guidelines and within the specified norms

\section{ETHICAL ISSUES FACED B Y GM INDIA}

In the first half of 2013 the Detroit-headquartered automaker's Indian arm, General Motors had admitted to the Indian government that their internal probe had revealed that the company had violated testing norms. Its employees had re-fitted already approved engines used in their new Tavera models that were sent for inspection in order that they meet the specified emission norms.

Another ethical code of conduct was violated when the company acknowledged that they manipulated the weight of several of its models in order to comply with less stringent emission norms. GM India acknowledged this in their letter to the Indian government on July 18, 2013 after they 'discovered' compliance failures. GM India immediately suspended production and the sales of two variants of Tavera.

Their investigations revealed that over a period of time some company employees had engaged in unethical practice of identifying engines with lower emission. These were fine-tuned and used for installation on vehicles during inspection.

On July 24, 2013 GM India announced the recall of over 1.14 lakh Chevrolet Taveras manufactured during 2005 and 2013 to specifically address 'emission and specification matters'. These pre-selected engines (instead of a random 
selection) were placed for selection to visiting inspectors.

Under Section 182A of the Motor Vehicles Act any violations and irregularities and is punishable including along with a monetary fine. If widespread collusion was established more serious provisions of the Indian Penal Code could be invoked

The Indian road transport ministry along with the project director of the National Automotive Testing and R\&D Infrastructure Project are jointly probing the Tavera case. They investigated GM India and the functioning of the government's testing facilities.

GM India passed off some vehicles as slightly heavier ones that enabled them to pass less stringent standards as the lighter vehicles have to meet more stringent emission norms.

A team of engineers and compliance professionals has been set up to urgently ensure compliance.

Within a week of their recall GM India has expelled top officials, including its chief financial officer Anil Mehrotra and the R\&D executives, for "violating company policies".

The GM's Detroit headquarters had also handed pink slips to around 20-25 of their senior officials. The head of global engine development Sam Winegarden was asked to leave. He had worked 44 years with GM.

Sheila Sarver Lavern Sula, and Ravi Desai, who were part of the GM India Technical Centre, is under investigation for failing to comply with regulations.

General Motors' investigation has identified violations of company policy and they are taking matters very seriously as they hold their leaders and employees to high standards. When those standards are not met, they will take the appropriate action to hold employees accountable.

According to experts, Frost \& Sullivan's South Asia it will be extremely difficult for the US firm to ensure that the Tavera recall would not impact its brand image and sales especially with their partners (dealers, suppliers) and their relationships with the regulatory authorities

Despite being in the Indian market for over 17 years with investments of over $\$ 1$ billion, the US car maker has not yet reached break even in India. GM India market share languishes at 3.2\%. Their losses swelled to INR 7460 million in FY12 from INR 1840 million in FY11. Their brands Beat, Spark, Cruze and Captiva are struggling in selling to Indian customers.

GM has a wide product portfolio however they still struggle to push their sales beyond the 100,000 mark. This setback will dent GM India's image further.

GM was the first company to targeting a market share of $10 \%$ in India and even after almost 5-6 years their market share is only about $3.2 \%$ market share at the end of FY13.

Their history in India has been a bumpy one. They had a rough patch with Opel cars and subsequently relied on the Chevrolet brand to make a strong comeback. GM India got cars from different parts of the globe. First it got Spark from Daewoo, Tavera from Isuzu, Sail twins and Enjoy from Chinese partner SAIC. They had Beat and Cruze from their own Chevy portfolio. Some of these products began well, but they could not sustain the momentum with the passage of time.

"Every product, after an initial good response had tapered off. GM pricing was aggressive however they lack aspiration.
They needed to bring in products which are adapted and specifically designed for India for Indian taste as many products in India have been adapted and designed for the different markets they are sold.

The recall is a setback for GM's India growth plans especially due to the damages in their reputation. According to Lowell Paddock, head of GM India, "Our customers are at the center of everything we do"

According to GM's chief executive, Daniel F. Akerson the decision to oust the errant executives is done in keeping with the "zero-tolerance policy" about violation of corporate ethics. These matters are very serious and they expect their leaders and employees to keep up the high standards. If there is violation in the standards then they will take appropriate action to hold their employees accountable.

This policy is consistent with time as seen during last year, Joel Ewanick, the chief marketing officer of GM was forced to resign after the controversial handling of a sponsorship deal with a British soccer team.

The Indian government has committed to plug the loopholes in the manufacturing practices of the auto industry. They check the authenticity of the quality parameters as there is an increasing number of technical snags and recalls.

In the past one year, in India there has been nine recalls of different vehicles varying from scooters, bikes, cars to SUVs however the latest recall of 140,000 units of Tavera was the biggest ever.

Two more models - diesel variants of Sail sedan and Sail UV-A hatchback are under investigation to fix emission and quality issues.

General Motors has started work with its dealers and the customers to change the catalytic converter in all the vehicles. Also in some vehicles the fuel pipe would also be changed. The dealers have been informed and they would change the required spare part. The entire work would take around 35-45 minutes at the service station and is expected to be performed free of charge.

This is the time wherein all the stakeholders can come together - the testing agencies, government, and the manufacturers - to devise a system that does not fail. What is more surprising is that this problem remained 'unidentified' for almost eight years. Experts, therefore conclude that employees resorted to such decision with the consent of top management and colluded with the testing officials. This is obviously strongly denied by GM India.

There is a need for meeting the emission norms continually otherwise the repercussions for the environment is enormous. One suggestion is a need for 'annual certification', tighter measures for the Conformity of Production (COP), and stricter punishments under the Indian Penal Code.

\section{CONCLUSIONS}

GM India has been very ambitious to achieve their target of market share in India and maintain their good sales record for the Head Office. Based on the 'Utilitarian' theory GM India is ethically right in achieving good for almost all the stakeholders; however there is the regulatory authorities and the environment norms that need to be adhered to in the code 
of conduct of the company. A shift of viewing this ethical dilemma can be addressed by the "Kantian" model that insists on the right moral duty of the individual in relation to decision making. In this model the acceptance of the framework and the symmetrical communication wherein there is a proper dialogue with the stakeholders, organization, public and society is maintained. The resultant code of conduct suggests a demonstrative leader who values team work and believes in justice that is fair without emotions. GM has initiated proactive action simultaneously adhering to their strategic vision to maintain their fast growing brand sales worldwide can be justified in an ethical manner.

\section{REFERENCES}

[1] W. Cordeiro, "Suggested management responses to ethical issues raised by technological change," Journal of Business Ethics, vol. 16, no. 12-13, 1997

[2] I. Kant, Immanuel Kant's Lectures on Ethics, Hackett Publishing Company, 1963, pp. ix-xiv.

[3] R. J. Sullivan, An Introduction to Kant's Ethics. New York: Cambridge University Press, 1994.

[4] A. Flew, A Dictionary of Philosophy, 2nd ed., New York: St. Martin's., 1979.

[5] S. A. Bowen, "A practical model for ethical decision making in issues management and public relations," Journal of Public Relations Research, vol. 17, no. 3, pp. 191-216, 2005.

[6] J. Bentham, The Principles of Morals and Legislation, Amherst, NY: Prometheus., 1988.

[7] J. S. Mill, Utilitarianism, New York: Liberal Arts, 1957.

[8] I. Kant, Groundwork of the Metaphysic of Morals, H. J. Paton, Trans. New York: Harper \& Row, 1964

[9] M. W. Baron, Kantian Ethics almost without Apology, Ithaca, NY: Cornell University Press, 1995.

[10] J. E. Grunig, "Two-way symmetrical public relations: Past, present, and future," in Handbook of Public Relations, R. L. Heath Ed, 2001, pp. 11-30.

[11] L. A. Grunig, J. E. Grunig, and D. M. Dozier, Excellent Public Relations and Effective Organizations: A Study of Communication Management in Three Countries, Mahwah, NJ: Lawrence Erlbaum Associates, Inc. 2002.

[12] R. Pearson, "Beyond ethical relativism in public relations: Co-orientation, rules, and the idea of communication symmetry," Public Relations Research Annual, vol. 1, pp. 67-86, 1989.

[13] A. N. Greenland, Learning About Product Quality: Automotive Recalls and Country Reputations, November 1, 2012.

[14] D. Vogel, "The globalization of business ethics: Why America remains different," California Management Review, vol. 35, no. 1, pp. 30-49, 1992.

[15] E. D. Jaffe and A. Tsimerman, "Business ethics in a transition economy: Will the next russian generation he any better," Journal of Business Ethics, vol. 2, no. 1, pp. 87-97, 2005.

[16] P. T. Heyne, G. Brennan, and A. M. C Waterman, "Are economists basically immoral," Essays Oneconomics, Ethics, and Religion, Library, p. 483, 2010

[17] B. A. B. Blonigen, C. R. C. Knittel, and A. Soderbery, "Keeping it fresh: Strategic product redesigns and welfare," National Bureau of Economic Research Working Paper Series, No. 18997, 2013.

[18] R. G. Hammond, "Sudden unintended used-price deceleration? The 2009-2010 Toyota recalls," Journal of Economics \& Management Strategy, vol. 22, no. 1, pp. 78-100, 2013.

[19] J. E. Alvey, "Ethics and economics, today and in the past," The Journal of Philosophical Economics, vol. 5, no. 1, pp. 5-34, 2011.

[20] J. C. Lere and B. R. Gaumnitz, "The impact of codes of ethics on decision making: Some insights from information economics," Journal of Business Ethics, vol. 48, no. 4, pp. 365-379, 2003.

[21] C. Barnes, "Why compliance programs fail: Economics, ethics and the role of leadership," HEC Forum, vol. 19, no. 2, pp. 109-23, 2007.

[22] A. Jamnik, "Ethics and economics: How can they be integrated into good business decision-making? An eastern european perspective,' Journal of International Business Ethics, vol. 5, no. 1, pp. 18-26, p. 62, 2012.
[23] Z. Yin, F. Xiaoliang, and H. Minxue, "When does a product recall hurt? An investigation on public response," in Proc. 2011 International Conference on Product Innovation Management ICPIM 2011.

[24] N. C. Smith, R. J. Thomas, and J. A. Quelch, "A strategic approach to managing product recalls," Harvard Business Review, 1996.

[25] C. Korkofingas and L Ang, "Product recall, brand equity, and future choice," Journal of Marketing Management, vol. 27, no. 9-10, pp. 959-975, 2011.

[26] D. Minor and J. Morgan, "CSR as reputation insurance: PRIMUM NON NOCERE," California Management Review, vol. 53, no. 3, pp. 40-59, 2011.

[27] T. Chu, C. Lin, and L. J. Prather, "An Extension of security price reactions around product recall announcements," Quarterly Journal of Business Economics, vol. 44, no. 1981, pp. 33-48, 2005.

[28] A. Zavyalova, M. D. Pfarrer, R. K. Reger, and D. L Shapiro, "Managing the message: The effects of firm actions and industry spillovers on media coverage following wrongdoing," Academy of Management Journal, vol. 55, no. 5, pp. 1079-1101, 2012.

[29] S. Jonsson, H. R. Greve, and T. F. Greve, "Undeserved loss: The spread of legitimacy loss to innocent organizations in response to reported corporate deviance," Administrative Science Quarterly, vol. 54, no. 2 , pp. 195-228, 2009.

[30] Y. Choi and Y. H Lin, "Consumer response to crisis: Exploring the concept of involvement in Mattel product recalls," Public Relations Review, vol. 35, no. 1, pp. 18-22, 2009.

[31] S. M. Freedman, M. S. Kearney, and M. Lederman, "Product recalls, imperfect information, and spillover effects: Lessons from the consumer response to the 2007 toy recalls," NBER Working Papers 15183, National Bureau of Economic Research, Inc, 2009.

[32] N. G. Rupp, “Are government initiated recalls more damaging for shareholders? Evidence from automotive recalls, 1973-1998," Economics Letters, vol. 71, no. 2, pp. 265-270, 2001.

[33] N. G. Rupp, "The attributes of a costly recall: Evidence from the automotive industry," Review of Industrial Organization, vol. 25, no. 1, pp. 21-44. 2004.

[34] D. Laufer and J. M. Jung, "Incorporating regulatory focus theory in product recall communications to increase compliance with a product recall," Public Relations Review, vol. 36, no. 2, pp. 147-151. 2010.

[35] G. Jarrell and S. Peltzman, "The impact of product recalls on the wealth of sellers," Journal of Political Economy, vol. 93, no. 3, p. 512, 1985.

[36] C. A. D. Matos, and C. A. V. Rossi, "Consumer reaction to product recalls: factors influencing product judgment and behavioral intentions," International Journal of Consumer Studies, vol. 31, no. 1, pp. 109-116, 2007.

[37] S. Govindaraj, "Market overreaction to product recall revisited," The Review of Quantitative Finance Accounting, vol. 1, pp. 31-54. 2004.

[38] Y. Chen, S. Ganesan, and Y Liu, "Does a Firm's Product-recall strategy affect its financial value? An examination of strategic alternatives during product-harm crises," Journal of Marketing, vol. 73, no. 6, pp. 214-226, 2009.

[39] M. Rhee and P. R. Haunschild, "The liability of good reputation: A study of product recalls in the U.S. automobile industry," Organization Science, vol. 17, no. 1, pp. 101-117, 2006.

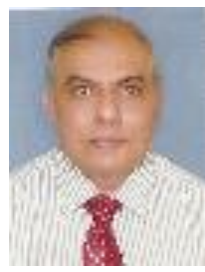

Thomas Mathew was born in India on Oct $10^{\text {th }} 1959$ he has a doctorate in General Management. He is also having a Masters in Science from Institute of Science, and Masters in Marketing Management from Jamnalal Bajaj Institute of Management one of the Top $10 \mathrm{~B}$ schools in India. $\mathrm{He}$ has also Post graduate specialization in Material Management from Wellingkars, Supply chain Management from ICFAI and I.T from Symbiosis.

$\mathrm{He}$ is having eight years of academic teaching experience at the $\mathrm{K} \mathbf{J}$ Somaiya Institute of Management Studies \& Research (SAAQS accredited). His main subjects are General Management, International Business and Strategy teaching the Master's Degree program of Mumbai University for the full time day scholars and the part time working executives. He has over two decades of international experience working in several multinational companies in various profiles before taking up academics. He has over forty papers presented and published in several National and International conferences and journals.

Dr. Thomas Mathew is an accredited Professor of Management by the All Indian Management Association and recognized Professor of Management by the Mumbai University for their Master's program. 